Review Article

\title{
Integrating Educational Games into College English Learning
}

\author{
Ming Li $(\mathbb{D}$, Qi Zhang $\mathbb{D}$, and Zhonggen Yu $\mathbb{D}$ \\ Faculty of Foreign Studies, Beijing Language and Culture University, 15 Xueyuan Road, Haidian District, Beijing 100083, China
}

Correspondence should be addressed to Zhonggen Yu; 401373742@qq.com

Received 7 October 2021; Accepted 6 December 2021; Published 16 December 2021

Academic Editor: Syed Sameer Aga

Copyright (C) 2021 Ming Li et al. This is an open access article distributed under the Creative Commons Attribution License, which permits unrestricted use, distribution, and reproduction in any medium, provided the original work is properly cited.

Currently, the application of educational games is becoming a hot topic, but the application of educational games in college English learning is scarcely explored. To explore the integration of educational games into the college English teaching and learning process, this study adopted a rapid evidence evaluation review (Yu et al. 2020). Since the literature review is an important approach in qualitative sampling techniques, we have conducted a review to identify and synthesize the literature. It analyzed high-quality journal articles published internationally and nationally. We found that educational games were effective in enhancing students' college English proficiency and learning attitudes. Meanwhile, playful experiences created by educational games could decrease cognitive loads in college English learning. This research provided some support for further implementation of educational games in the college English teaching and learning process.

\section{Introduction}

The 21st century has witnessed the rapid development of computer science and network technology, which has given birth to a new type of popular entertainment: computer games [1]. In recent years, computer games have developed rapidly and have formed a new industry [1]. With the rise of the digital game industry, many games software have been developed and available on the market. There was "a mad rush" to integrate educational content into games "in an ad hoc manner" and video games were used for educational purposes [2].

Educators have studied how to combine school education and games to relax students and make it possible to acquire the required knowledge and academic skills. Thus, freeing students from traditional computer games makes computer games play a positive role in their growth and positively impact them. Computer games could be applied to the teaching and learning processes. At the same time, learning elements could contain the outstanding magic elements of computer games. It is a question worthy of consideration in the current education strategy [3], which advocates the transformation from examoriented to quality education.
The study mainly focuses on the integration of educational games into college English teaching and learning process to improve students' attitudes and their learning effectiveness. For further explanation, we mainly explore the relationship between educational games and college English teaching from three dimensions: English proficiency, learners' attitude, and cognitive loads. The study explores the relationships between educational games and college English proficiency, the connection between educational games and learners' attitudes to college English learning, and the correlation between playful experiences created by educational games and cognitive loads.

\section{Literature Review}

Educational games, also called serious games, digitallearning games, educational video games, or digital educational games, take educational content as the design theme and core to enhance learning [4]. As a sort of digital media, educational games incorporate the content of knowledge into games and are increasingly popular [5]. More recent attention has focused on computer games as the optimal tool for education [6]. A relatively small body of literature is concerned with the integration of educational games into 
college English teaching and learning process to improve students' attitudes and their learning effectiveness, such as English proficiency, learners' attitudes, and cognitive loads [7].

2.1. College English Proficiency. College English learning proficiency is a comprehensive evaluation and feedback to assess students' English abilities. College English proficiency could be described in numerous dimensions. However, according to the EF EPI-s (English Proficiency Index for Schools), a study of the acquisition of English skills by secondary and tertiary students (https://www.ef.com/ca/epi/ about-epi/proficiency-bands/), there are five proficiency bands: very high proficiency, high proficiency, moderate proficiency, low proficiency, and very low proficiency (https://www.ef.com/ca/epi/about-epi/proficiency-bands/). Chinese learners have moderate proficiency in English (a proficiency level merely indicates the "average" person's level) (https://www.ef.com/ca/epi/about-epi/proficiencybands/). To the author's knowledge, almost every college student has learned English at least nine years old, ranging from elementary school, middle school, and high school [8-10]. The overall national pass rate for CET-4 is about $40 \%$, and the pass rate for the second exam is almost $60 \%$ (What is the pass rate of college English test-4 [11], and its embarrassing results?). Existing studies present the impact of educational games on college English proficiency. As a methodological solution, educational games could promote personalized English learning, especially in CET-4 vocabulary mastery $[6,12]$. Improving English scores and proficiency is more accessible through gamified instruction than through the traditional teaching method [6]. Educational games could bring students magical English learning experiences, making English listening, speaking, and grammar courses readily accepted.

Educational games could help achieve learning goals, develop English reading skills, and improve language proficiency [13]. Some studies claim that serious games could significantly impact students' English level and proficiency ( e.g., [14] video games could impact learning effects in contrast with no educational game teaching [15] and are precious learning methods for learning English idioms [16]). Educational games provided an excellent platform to show English level in language pragmatics [17] and linguistic competencies [18].

However, some studies showed educational games had an insufficiently significant effect on English learning proficiency. It could be estimated that there is no consensus on the utility of educational games in college English learning. Under certain circumstances (suppose there is little instructional support or an inappropriate choice of educational games in the English language), the educational games' effects could be significantly reduced [19]. In addition, some authors addressed that learning needs joyfulness, whether there are learning outcomes or not [20].

Taken together, previous studies provided essential insights into educational games used to support learners' college English proficiency. Educational games could promote students' language learning proficiency overall and positively affect English learning [3, 21]. These statements have to be further demonstrated in educational contexts. Thus, we have raised the following research question:

RQ1: Can educational games positively impact college English proficiency?

\subsection{Attitude and Acceptance in College English Learning.} Learners' attitude and acceptance are other essential factors that influence the efficiency of game-based learning, which shapes the game-based learning model and influences their self-awareness, acceptance degree of technology, and learning [22]. Gamification experiences correlated with learners' attitudes in a case study of English vocabulary learning [23]. Educational games influence learners' attitudes, promote self-awareness and self-regulated learning, which intrinsically motivates learners compared to traditional classrooms, and learners are active and do not merely listen $[24,25]$.

However, there is a lack of remarkable compatibility or similarity between the groups in educational games and the group in nongame situations regarding attitudes towards English courses. Learners' English academic achievement tests based on game-based learning performed better than those without game situations [26]. The study attempted to explore the connection between educational games and learners' attitudes to acceptance of college English learning.

Positive learners' acceptance of technology-based English learning could be significantly improved [27]. Learners' acceptance of technology increases, and their learning ability becomes robust. [28-30]. Serious games could improve student learning effects; empower learners' acceptance of learning [31]. Learning in a game environment and through immersive experiences is critical and meaningful [32]. Thus, educational games are more effective for student enjoyment, contributing to learners' acceptance of game-based learning [33].

It could be found that educational games could change learners' attitudes towards and acceptance of college English learning generally through past studies. Gamification positively impacts successful technique adoption and overall learning attitude [34]. Moreover, educational games will help the teachers strategically motivate the students to learn English better [35]. Learners' awareness of applying knowledge in educational games to practical interaction could indicate the acceptance of gamified experiences in terms of knowledge application [36]. So we have raised the following research question:

RQ2: Can educational games enhance learners' attitudes towards and acceptance of college English learning?

2.3. Playful Experiences and Cognitive Loads in College English Learning. Serious games can provide playful experiences full of entertainment, motivating learners to explore the joyful way of learning tasks [20], since they can supply enough freedom for students [37]. Additionally, research has 
indicated that joyful experiences from playing video games could improve cognitive abilities and emotional and social problem solving [21]. This study investigated the correlation between educational games and playful experiences and cognitive loads in college English learning.

The playful purposes of educational games could effectively decrease learners' cognitive load rate [38]. Gamelike experiences are mixed with playful aspects in English learning activities [39]. Exciting experiences are rewarding for reducing the cognitive load in college English learning. Learners address "English is not easy, but I like it!" [40]. Meanwhile, the adverse effect of foreign language listening is an increase in anxiety [41]. Educational games could reduce learning anxiety and offer a relaxed and comfortable learning atmosphere [18].

In most cases, we found some correlations between the playful experiences created by educational games and cognitive loads by reviewing comparative studies. Here cognitive loads were only discussed in the general sense. So we have raised the following research question:

RQ3: Can playful experiences created by educational games decrease cognitive loads in college English learning?

\section{Methods}

3.1. Research Design. The research design adopted a rapid evidence evaluation review [42]. We selected journal articles published internationally and nationally. We analyzed several main viewpoints from two dimensions based on specific criteria by searching and extracting keywords about educational games and college English learning [43]. We carried out an analysis of the results.

3.2. Research Corpus. The study included three steps of selecting academic journals ( Figure 1), i.e., academic journal searching, keyword clustering, and results extracting.

The author searches literature using All Fields to ensure all papers are related to the same field. The author got 19,939 results by keying in (educat*) AND (gam*) AND (learn*) AND (English) as All Fields in Web of Science database.

By limiting the Web of Science Categories to Educational Research, keying in (college) as All Fields in the Web of Science database, searching nearly three years closely relevant to the research subject and removing lower quality papers, the author finally limited papers to 481 results. We researched through the bibliographic network by the program VOSviewer and obtained a data map drawing from the Web of Science database,

By selecting co-occurrence as the analysis type, choosing total count as the counting method, and selecting all keywords as the analysis unit, we set the minimum number of occurrences of a keyword at 2. Of the 246 keywords, 41 meet the thresholds. For each of the 41 keywords, the total strength of the co-occurrence links with other keywords was calculated. The keywords with the greatest total link strength were selected ( Figure 2). For each of the 41 keywords, we calculated the total strength of co-occurring links with other

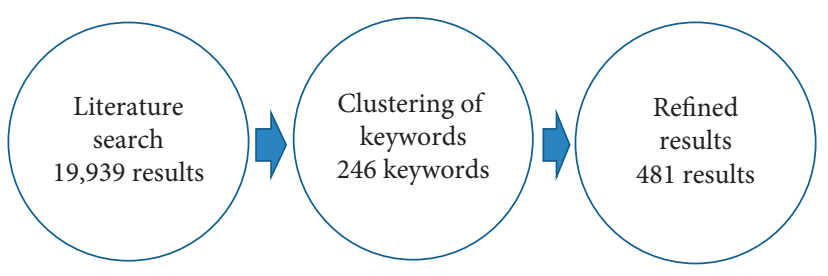

Figure 1: Process of literature selection.

keywords and chose the keyword with the greatest total link strength ( Figure 2). Keywords were divided into seven categories and forty-one items ( Table 1; Figure 2).

The total link strength $(N=43)$ of education is the top item. The second item is computer games with a strong link strength $(N=38)$. The link strengths of English learning $(N=30)$ and impact $(N=28)$ are also highly ranked. The clustering process thus demonstrated that game-based English learning, computer games, system, impact, and motivation were significant research themes in recent decades (Figure 3).

3.2.1. Sampling Strategy. We retrieved as many high-quality academic papers as possible and obtained purposive samples further to refine the results to educational game-based college English learning.

3.2.2. Type of Studies. The author selected rigidly designed studies using qualitative, quantitative, or mixed methods.

3.2.3. Approach. The author retrieved the data using a hand search method. Through the Boolean search method, the study chose the terms educational games, satisfaction, college English learning, effect, character, and attitude as All Fields. To refine the results, the author limited the results via the following approaches.

3.2.4. Range of Years. The author selected results ranging from January 2008 to September 2021. The year 2008 witnessed the commencement of studies on game-based learning in some disciplines, remaining a lower level until 2015 when the studies surged up, arriving at the peak in 2019. The years 2020 and 2021 saw a decline (Figure 4). The data was retrieved in September 2021. Relevant studies in 2021 were thus not thoroughly revealed.

The author selected the results from January 2008 to September 2021. In 2008, gamified learning research was carried out in some academic areas and kept at a low level until the surge in research in 2013, reaching the top in 2019. There will be a decline in 2020 and 2021 (Figure 4). The data was retrieved in September 2021, and the relevant research in 2021 was not fully revealed.

3.2.5. Inclusions and Exclusions. Both inclusion and exclusion criteria were used to refine the results and to obtain high-quality publications. The inclusion criteria were as follows: (1) the study time ranged from January 2008 to 


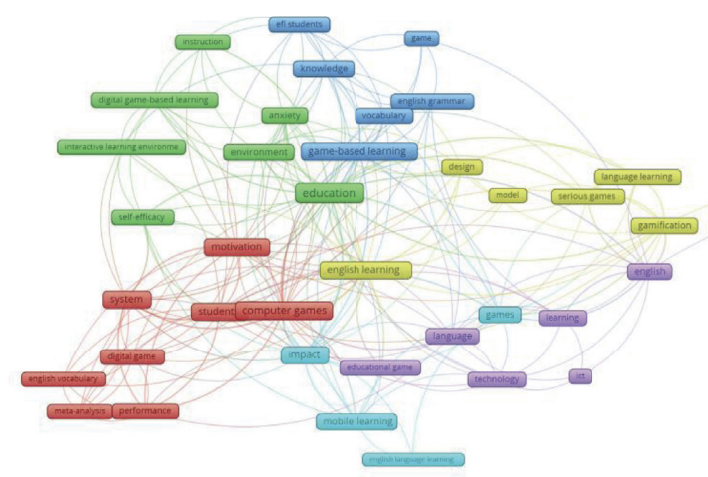

Anoswewer

Figure 2: Cluster of keywords.

TABle 1: Cluster of keywords.

\begin{tabular}{lr}
\hline Category & Item \\
\hline Cluster 1 & Computer games, system, students, motivation, performance, digital game, English vocabulary, and meta-analysis \\
Cluster 2 & Education, anxiety, environment, self-efficacy, digital game-based learning, instruction, and interactive learning environments \\
Cluster 3 & Game-based learning, knowledge, vocabulary, EFL students, English grammar, and game \\
Cluster 4 & English learning, gamification, serious games, design, language learning, and model \\
Cluster 5 & English, language, technology, learning, educational game, and ICT \\
Cluster 6 & Impact, games, mobile learning, and English language learning \\
Cluster 7 & Educational games, college English teaching, English proficiency, and strategies \\
\hline
\end{tabular}

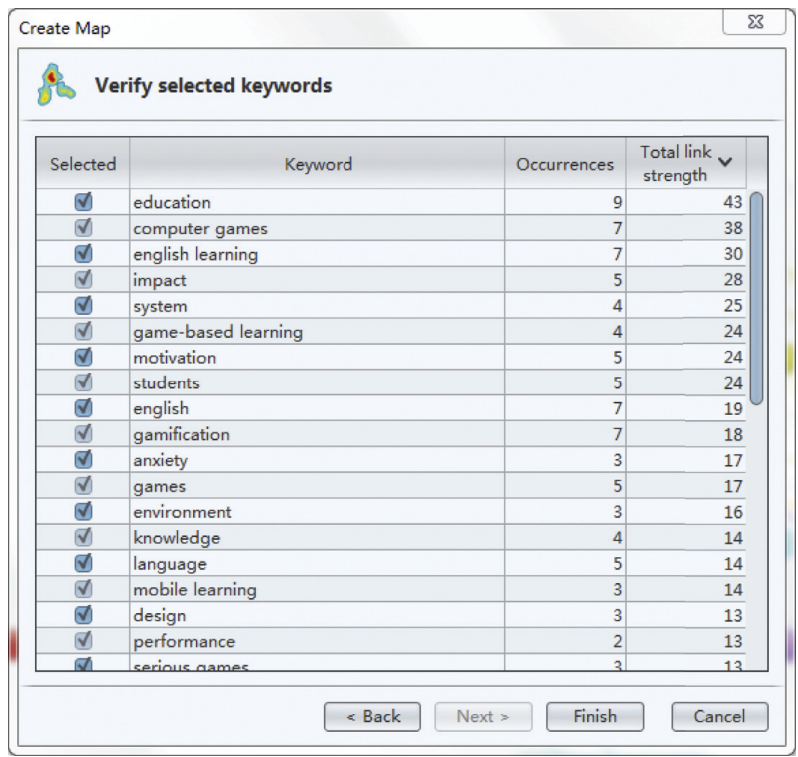

FIGURE 3: Keywords and total link strength.

September 2021; (2) the study shed light on the educational game, serious game, college English learning, teaching, and learning effects; (3) the study investigated educational game, serious game, college English learning, teaching, and learning effects in the game-based college English learning context compared with other contexts; and (4) the research methods of the selected studies were qualitative, quantitative, or mixed.
The exclusion criteria were as follows: (1) the study conducted before January 2008 and after September 2021; (2) the study did not investigate educational game, serious game, college English learning, teaching, and learning effects in the game-based college English learning context; (3) the study was book chapters, reports, or unpublished works; and (4) the study did not compare the game-based college English learning context with other contexts. 


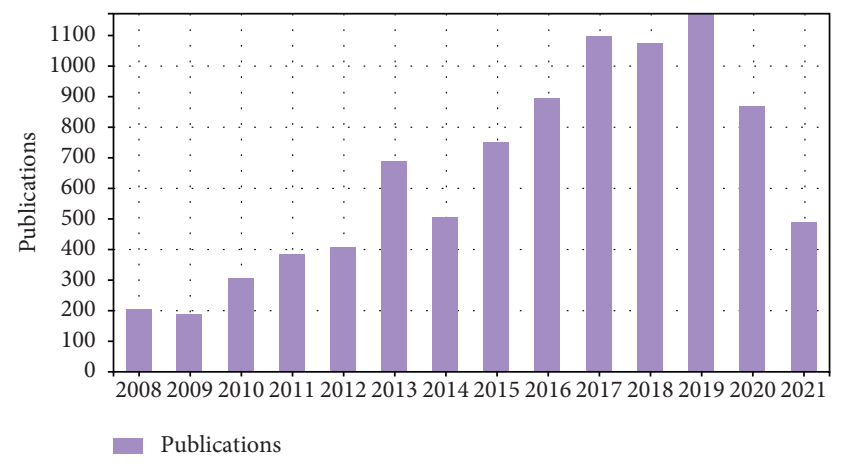

FIgURE 4: The number of publications on game-based learning.

3.2.6. Terms Used. The search terms include educational game, serious game, college English learning, teaching, and learning effects.

3.2.7. Electronic Sources. The sample was sourced from the Web of Science (core collection).

\section{Results}

The study explores the relationships between educational games and college English proficiency, the connection between educational games and learners' attitudes towards and acceptance of college English learning, and the correlation between playful experiences created by educational games and cognitive loads. We found a significant positive correlation between educational games and college English teaching and the learning process.

\subsection{RQ1: Can Educational Games Positively Impact College} English Proficiency? The study with qualitative research found that educational games support English language learning, positively impacting college English proficiency [44]. From assessment systems' information feedback on the degree of English learning performance, the result found that educational games enhance learning performance and actual English level [45].

Current studies present that educational games could provide helpful input. Game-based learning could improve students' academic performance, especially language skills [46], and promote language fluency. An investigation showed that the English proficiency of undergraduate learners was greatly enhanced with a game-based learning approach. At the same time, game-based learning could effectively reduce interference from traditional classrooms [47].

Computer game-assisted English learning could lead to better academic achievements than in a nongame context and improve students' language proficiency [26]. Educational games were remarkably effective in English learning, especially vocabulary acquisition [48]. Gaming characteristics and game availability were beneficial to vocabulary learning [44]. Educational games could be applied to sound feedback vocabulary capacity in paper examination [49]. "Serious games played a leading role in promoting
English vocabulary learning" [50]. Through pedagogical practices, educational games greatly affect language teaching and proficiency. Accordingly, game-based learning could directly influence learners' spoken English proficiency [51].

Thus, educational games positively impact language learning [52]. Some studies claim that educational games have negative impacts. Furthermore, there was no sufficient empirical evidence confirming that educational games improve language capability and proficiency [21]. Although there are debates over educational games, numerous studies have proved that educational games could positively impact college English proficiency [53].

4.2. RQ2: Can Educational Games Enhance Learners' Attitudes towards and Acceptance of College English Learning? Some literature suggested that language learners' attitude could be significantly improved while educational game goals were achieved [54]. Educational games molded learners' attitudes and promoted self-regulated learning [55]. Educational games also enhance language learners' attitudes to English learning. Some surveys reported that Chinese college students majoring in English or English translation were able to provide thoughtful insights into their language learning during game-based teaching and learning processes ( e.g., [1] language learners' attitudes towards learning goals and materials could be more confident and ambitious, and they could motivate themselves to learn further on purpose) [48].

Some studies suggested that educational games were readily accepted due to game-like formats, visual materials, and enjoyment [56]. Researchers addressed that educational games could be helpful for students' online or classroom learning, alone or in groups [57]. At the same time, educational games might present prizes, rewards, and practical feedback to activate learners to enhance their English learning. Educational games "put the learner in a decisionmaking role" [58]. In addition, some interventions in educational games might be specially designed to improve learners' learning attitudes [59].

The ever-increasing popularity of educational games has a strong positive impact on learners' attitudes [60] towards and acceptance of college English learning. English learners could be more confident and optimistic in educational games. Then, their positive attitudes could inspire learners to improve their English learning, for educational games are paced to learners' aptitudes [61]. Thus, the study supports the idea that educational games can enhance learners' attitudes towards and acceptance of college English learning.

4.3. RQ3: Can Playful Experiences Created by Educational Games Decrease Cognitive Loads in College English Learning? When we inquire into the English outcomes based on educational games, students' playful experiences and cognitive loads cannot be ignored. Entertaining gaming familiarity seems to be an essential aspect of English success, especially for second language learners [38]. Joyful gaming familiarity as a factor for English proficiency in game-based learning 
could not be avoided. Gaming experience might significantly improve English level and reduce cognitive load with educational games [38]. The empirical study revealed that all students' language skills were almost the same in the pretest, but the gaming group performed significantly better than the opposite pattern. Surprisingly, learning outcomes were negatively correlated with overall cognitive load [62].

English learning is usually accompanied by anxiety [63]. Anxiety levels negatively correlate with learning performance [64]. Game-assisted English learning revealed that gaming performance affected anxiety levels and resulted in participants' performance accordingly. Existing literature demonstrates high-anxiety students performed worse in traditional classroom teaching; high-anxiety and low-anxiety students performed at a similar level in gaming performance [64]. Digitally-oriented learning is particularly beneficial to high-anxiety learners, for educational games are helpful to reduce the level of anxiety, significantly to ease the level of high-anxiety students in language learning.

However, some researchers express some concerns about educational games. Suppose the element of fun is taken out, then educational games are "chocolate-covered broccoli" [21]. Some competitive games could frustrate students who have poor English academic performance and are unmotivated [64]. To some degree, game users and designers balance the educational aspects and the entertainment [65]. However, educational games are generally still a playful supplement tool to college English learning.

Overall, playful experiences mediate educational games' effects on decreasing cognitive loads with college English learning. The study found that playful experiences created by educational games can lower cognitive loads in college English learning.

\section{Discussion}

The study emphasized three issues: educational games can positively impact college English proficiency; educational games can enhance learners' attitudes towards and acceptance of college English learning; and playful experiences created by educational games can decrease cognitive loads in college English learning. We have discussed the directive functions of educational games for language learning and teaching in the future.

\subsection{The Role of English Proficiency in College English Learning.} College English learners are usually regarded as having moderate English proficiency, and some are even lower [50]. Meanwhile, as one of the most commonly used languages globally, English is a communication tool. English proficiency plays a crucial role in evaluating college English learning success. One of the goals of college English learning is to improve proficiency. Educational games should be thoroughly combined with the characteristics of the English language to enhance learners' language proficiency. On the other hand, it is necessary to improve the interaction between learners and educational games and maximize the value of educational games for learners to improve English outcomes.

5.2. Changes in Learners' Attitudes towards and Acceptance of Game-Based Education. Educational games could positively affect learners' attitudes to learning [66]. Learners were more motivated to prepare for exams but put much more effort into the game-based learning experiment [67] than in the traditional classroom. Learners' outstanding performances could demonstrate effective game-based learning and foster English proficiency. The study has revealed that learners have positive attitudes towards and acceptance of gamebased approaches in English learning. Educational games have significant influences on learners' attitudes, intrinsically and extrinsically.

5.3. Playful Experiences and Cognitive Loads. A playful and joyful affordances model of educational games created a model of authentic learning, which might combine immersive English learning with active pedagogy [68]. In contrast to classroom learning that could aggravate cognitive loads, game-based learning could comfortably facilitate English learning. A game environment provides learners with a safe and nonthreatening environment. It minimizes the threat from the traditional classroom, which may result from being afraid of making mistakes and lower cognitive load ratings [41].

\section{Conclusion}

6.1. Major Findings. The study mainly focuses on the integration of educational games into college English teaching and learning process to improve students' attitudes and their learning effectiveness. We found a strong relationship between educational games and college English learning. Through further exploration, we found that educational games could positively impact students' college English proficiency, enhancing students' attitudes towards and acceptance of college English learning. Accordingly, playful experiences created by educational games can decrease cognitive loads in college English learning.

Regarding the overall positive effects of educational games on college English proficiency, we found that educational games can positively impact college English proficiency in all aspects of English. We should apply educational games to English learning and teaching.

Additionally, we found that educational games greatly influence learners' attitudes towards and acceptance of college English learning both intrinsically and extrinsically. Henceforth, we should apply educational games to college English teaching and learning.

Lastly, we found that educational games could create a relaxing and comfortable environment, and learners with playing experience could alleviate cognitive loads in English learning activities. We should reasonably apply educational games to college English teaching and learning. 
The main conclusions of this study are that educational games have overall positive impacts on college English proficiency and that educational games can enhance learners' attitudes towards and acceptance of college English learning. That playful experiences created by educational games can decrease cognitive loads in college English learning.

6.2. Limitations. There are still several limitations to this study. The sample is limited to research papers from the Web of Science (core collection), excluding book chapters, reports, or unpublished works, leading to inadequate resources. An additional uncontrolled factor is the possibility that the selection of the publications is based on the author's scope field. The inclusion criteria might have been narrowed so that we might have missed some critical academic articles. Moreover, we retrieved the publications mainly in English in this study, possibly resulting in publication bias. Finally, the study carried out qualitative research without statistic collection, so the reliability of the results might have been reduced.

6.3. Future Research Directions. This study could provide guides and recommendations for the potential use of game(s) in college English courses. These statements have presented the following directions for future research: we could conduct experiments examining the correlation between learners' acceptance of online device-supported classes and English proficiency. Additionally, we could conduct studies on the correlation between cognitive load and English proficiency.

\section{Data Availability}

Data supporting this research article are available from the corresponding author on reasonable request.

\section{Conflicts of Interest}

The authors declare that they have no conflicts of interest.

\section{Acknowledgments}

This work was supported by the 2019 MOOC of Beijing Language and Culture University (MOOC201902) (Important) "Introduction to Linguistics"; "Introduction to Linguistics" of online and offline mixed courses in Beijing Language and Culture University in 2020; and Special fund of Beijing Co-Construction Project: Research and reform of the "Undergraduate Teaching Reform and Innovation Project" of Beijing Higher Education in 2020-Innovative "Multilingual +" Excellent Talent Training System (202010032003).

\section{References}

[1] X. J. Wang and J. Dostal, "Using digital educational games for English foreign language learning," in Proceedings of the Edulearn18: 10th International Conference on Education and
New Learning Technologies, L. G. Chova, A. L. Martinez, and I. C. Torres, Eds., pp. 144-148pp. 144-, Palma, Spain, 2018.

[2] G. A. Gunter, R. F. Kenny, and E. H. Vick, "Taking educational games seriously: using the RETAIN model to design endogenous fantasy into standalone educational games," Educational Technology Research and Development, vol. 56, no. 5-6, pp. 511-537, 2008.

[3] A.-N. Lay and K. Osman, "Developing 21st century chemistry learning through designing digital games," Journal of Education in Science, Environment and Health, vol. 4, no. 1, pp. 81-92, 2018.

[4] B. Roungas and F. Dalpiaz, "A model-driven framework for educational game design," in Proceedings of the Games and Learning Alliance: 4th International Conference, GALA 2015, A. d. Gloria and R. Veltkamp, Eds., pp. 1-11pp. 1-, Switzerland, 2015.

[5] M. Kebrichi, "Factors affects teachers' adoption of educational computer games: a case study," British Journal of Educational Technology, vol. 41, no. 2, pp. 256-270, 2010.

[6] Z. G. Yu, "Comparative effectiveness between game-enhanced and pencil-and-paper English vocabulary learning approaches," International Journal of Gaming and ComputerMediated Simulations, vol. 10, no. 2, pp. 1-20, $2018 \mathrm{a}$.

[7] X. L. Huang, J. H. He, and H. Y. Wang, "A case study: students' perception of a collaborative game-based virtual learning environment," in Proceedings of the 6th International Conference of the Immersive-Learning-Research-Network (iLRN), D. Economou, A. Klippel, A.. , H. Dodds et al., Eds., pp. 46-53pp. 46-, San Luis Obispo, CA, USA, June 2020.

[8] W. F. Wang and X. S. Gao, "English language education in China: a review of selected research," Journal of Multilingual and Multicultural Development, vol. 29, no. 5, pp. 380-399, 2008.

[9] X. W. Wang and W. Z. Zhang, "Review of domestic research on foreign language learning motivation," Foreign Language World, vol. 4, pp. 58-65, 2005.

[10] W. Xu and R. E. Case, "Age-related differences in motivation in learning English among Mainland Chinese students," International Journal of Applied Linguistics, vol. 25, no. 1, pp. 67-82, 2015.

[11] What Is the Pass Rate of College English Test-4 (CET-4), Retrieved October 6, 2021, from https://www.hjenglish.com/ yuandan/p1333677/, Toronto, New-York, USA, 2020.

[12] L. L. Huang, F. H. Lin, and Z. X. Wang, "Online vocabulary quizMASter game for college English test band 4," in Proceedings of the IEEE SmartWorld, Ubiquitous Intelligence \& Computing, Advanced \& Trusted Computing, Scalable Computing \& Communications, Cloud \& Big Data Computing, Internet of People and Smart City Innovation (SmartWorld/ SCALCOM/UIC/ATC/CBDCom/IOP/SCI), G. Wang, Q. Han, M. Z. A. Bhuiyan et al., Eds., pp. 2017-2021, Leicester, UK, August 2018.

[13] D. Hooshyar, M. Yousefi, and H. Lim, “A procedural content generation-based framework for educational games: toward a tailored data-driven game for developing early English reading skills," Journal of Educational Computing Research, vol. 56, no. 2, pp. 293-310, 2018.

[14] A. L. Shi, Y. M. Wang, and N. Ding, "The effect of game-based immersive virtual reality learning environment on learning outcomes: designing an intrinsic integrated educational game for pre-class learning," Interactive Learning Environments, Advance Online Publication, 2019.

[15] Z. G. Yu, "Differences in serious game-aided and traditional English vocabulary acquisition," Computers \& Education, vol. 127, pp. 214-232, 2018b. 
[16] P. Thornton and C. Houser, "Using mobile phones in English education in Japan," Journal of Computer Assisted Learning, vol. 21, no. 3, pp. 217-228, 2010.

[17] G. T. Jackson, P. Inglese, J. Wain, V. Timpe-Laughlin, and L. Grace, "Measuring English pragmatics skills through gamebased performance," Bulletin of the Technical Committee on Learning Technology, vol. 19, no. 1, pp. 10-13, 2017.

[18] P. Krystalli, "Using educational online games to develop linguistic competences in foreign language learning," in Proceedings of the INTED2015 Conference, pp. 5338-5346, Spain, March 2015.

[19] J. R. Calvo-Ferrer and J. Belda-Medina, "Students' satisfaction in L2 terminology acquisition with video games: a case study," Porta Linguarum, vol. 24, pp. 179-190, 2015.

[20] J. J. He, Y. Lee, B. Young, and F. K. Chiang, "A Study on the effect of joyful learning application upon undergraduate English vocabulary learning," in Proceedings of the International Conference of Educational Innovation through Technology, J. Liu, S. Nishimura, H. Zhang, and Q. Jin, Eds., pp. 288-292pp. 288-, Osaka, Japan, December 2017.

[21] I. Granic, A. Lobel, and R. C. M. E. Engels, "The benefits of playing video games," American Psychologist, vol. 69, no. 1, pp. 66-78, 2014.

[22] D. F. Mellard, T. Krieshok, E. Fall, and K. Woods, "Dispositional factors affecting motivation during learning in adult basic and secondary education programs," Reading and Writing, vol. 26, no. 4, pp. 515-538, 2013.

[23] J. Marti-Parreno, E. Mendez-Ibanez, and M. J. MiquelRomero, "Attitude toward educational video games: the role of engagement," in Proceedings of the EDULEARN19: 11th International Conference on Education and New Learning Technologies (EDULEARN), L. G. Chova, A. L. Martinez, and I. C. Torres, Eds., pp. 5909-5913, Valencia, Spain, July 2019.

[24] R. Garris, R. Ahlers, and J. E. Driskell, "Games, motivation, and learning: a research and practice model," Simulation \& Gaming, vol. 33, no. 4, pp. 441-467, 2002.

[25] H. Tüzün, M. Yılmaz-Soylu, T. Karakuş, Y. İnal, and G. Kizllkaya, "The effects of computer games on primary school students' achievement and motivation in geography learning," Computers \& Education, vol. 52, no. 1, pp. 68-77, 2009.

[26] S. Yeşilbağ, Ö. Korkmaz, and R. Çakir, "The effect of educational computer games on students' academic achievements and attitudes towards English lesson," Education and Information Technologies, vol. 25, pp. 5339-5356, 2020.

[27] J. C. Yang, Y. L. Lin, J. J. Wu, and K. H. Chien, "Design and evaluation of a physical interactive learning environment for English learning," in Proceedings of the Digital 2008: Second IEEE International Conference on Digital Game and Intelligent Toy Enhanced Learning, M. Eisenberg, Ed., Banff, AB, Canada, November 2008.

[28] M. Griffiths, "The educational benefits of videogames," Education and Health, vol. 20, pp. 47-51, 2002.

[29] S. Parsons, A. Leonard, and P. Mitchell, "Virtual environments for social skills training: comments from two adolescents with autistic spectrum disorder," Computers \& Education, vol. 47, no. 2, pp. 186-206, 2006.

[30] D. Scattone, "Social skills interventions for children with autism," Psychology in the Schools, vol. 44, no. 7, pp. 717-726, 2007.

[31] C. Alonso- Fernández, I. Martínez -Ortiz, R. Caballero, M. Freire, and B. Fernández- Manjón, "Predicting students' knowledge after playing a serious game based on learning analytics data: a case study," Journal of Computer Assisted Learning, vol. 36, no. 3, pp. 350-358, 2020.

[32] K. D. Squire, "Video game-based learning: an emerging paradigm for instruction," Performance Improvement Quarterly, vol. 21, no. 2, pp. 7-36, 2008.

[33] N. Charlier and B. De Fraine, "Game-based learning as a vehicle to teach first aid content: a randomized experiment," Journal of School Health, vol. 83, no. 7, pp. 493-499, 2013.

[34] S. Samson and D. S. V. Karthiga, "Gamification as a tool in English language teaching," International Journal of Early Childhood Special Education, vol. 12, no. 2, pp. 99-102, 2020.

[35] R. Anyaegbu, "Teachers' thoughts on the integration of computer games in the ESL classroom in Nigeria," in Proceedings of the 4th European Conference on Games-Based Learning, B. Meyer, Ed., pp. 421-428, Rijeka, Croatia, 2010.

[36] R. Hämäläinen, "Using a game environment to foster collaborative learning: a design-based study," Technology, Pedagogy and Education, vol. 20, no. 1, pp. 61-78, 2011.

[37] $\mathrm{Z}$. Yu, "The effect of educational games on learning outcomes, student motivation, engagement and satisfaction," Journal of Educational Computing Research, vol. 59, no. 3, pp. 522-546, 2021.

[38] K. D. Stiller and S. Schworm, "Game-based learning of the structure and functioning of body cells in a foreign language: effects on motivation, cognitive load, and performance," Frontiers in Education, vol. 4, no. 18, 2019.

[39] R. W. Songer and K. Miyata, "A playful affordances approach to the design of gameful learning," International Journal of Engineering Education, vol. 32, no. 1, pp. 468-478, 2016.

[40] I.-F. Chung and Y.-C. Huang, "“English is not easy, but i like it!": an exploratory study of English learning attitudes amongst elementary school students in Taiwan," Educational Studies, vol. 36, no. 4, pp. 441-445, 2010.

[41] M. H. Liu and H. L. Xu, "Foreign language listening anxiety scale on students' English listening test performance," Frontiers in Psychology, vol. 12, 2021.

[42] Z. Yu, M. Gao, and L. Wang, "The effect of educational games on learning outcomes, student motivation, engagement and satisfaction," Journal of Educational Computing Research, vol. 59, no. 3, pp. 522-546, 2020.

[43] A. Booth, “"Brimful of STARLITE” toward standards for reporting literature searches," Journal of the Medical Library Association, vol. 94, no. 4, pp. 421-429, 2006.

[44] Z. H. Xu, Z. Chen, L. Eutsler, Z. H. Geng, and A. Kogut, "Scoping review of digital game-based technology on English language learning," Educational Technology Research and Development, vol. 68, no. 3, pp. 877-904, 2020.

[45] R. Sun, H. H. Zhang, J. Li, J. Zhao, and P. Dong, "Assessmentfor-learning teaching mode based on interactive teaching approach in college English," International Journal of Emerging Technologies in Learning, vol. 15, no. 21, 2020.

[46] H. J. H. Chen and H. L. Hsu, "The impact of a serious game on vocabulary and content learning," Computer Assisted Language Learning, vol. 33, no. 7, pp. 811-832, 2020.

[47] N. Almusharraf, "Incorporation of a game-based approach into the EFL online classrooms: students' perceptions," Interactive Learning Environments, vol. 0, pp. 1-14, 2021.

[48] T. Christopher and S. Von Gillern, "Video-game based instruction for vocabulary acquisition with English language learners: a Bayesian meta-analysis," Educational Research Review, vol. 30, 2020.

[49] T. Govender and J. Arnedo-Moreno, "An analysis of game design elements used in digital game-based language learning," Sustainability, vol. 13, no. 12, 2021. 
[50] Q. Wu, J. W. Zhang, and C. Y. Wang, "The effect of English vocabulary learning with digital games and its influencing factors based on the meta-analysis of 2,160 test samples," International Journal of Emerging Technologies in Learning, vol. 17, no. 17, pp. 85-100, 2020.

[51] N. Bado, "Game-based learning pedagogy: a review of the literature," Interactive Learning Environments, 2019.

[52] P. Nianfan, "TI performance evaluation of English learning through computer mode using neural network and AI techniques," Journal of Intelligent \& Fuzzy Systems, vol. 40, no. 4, pp. 6949-6959, 2021.

[53] M. M. McGill, C. Johnson, J. Atlas et al., "If memory serves: towards designing and evaluating a game for teaching pointers to undergraduate students," in Proceedings of the ITICSE-WGR'17: Proceedings of the 2017 ITICSE Conference Working Group Reports, pp. 25-46, ACM, Bologna, Italy, July 2017.

[54] C. Y. Chang, C. H. Kao, G. J. Hwang, and F. H. Lin, "From experiencing to critical thinking: a contextual game-based learning approach to improving nursing students' performance in electrocardiogram training," ETR\&D-Educational Technology Research and Development, Advance Online Publication, vol. 68, no. 3, pp. 1225-1245, 2019.

[55] J. Ramón, "Educational games as stand-alone learning tools and their motivational effect on L2 vocabulary acquisition and perceived learning gains," British Journal of Educational Technology, vol. 48, no. 2, pp. 264-278, 2017.

[56] R. Estriegana, J. A. Medina-Merodio, and R. Barchino, "Student acceptance of virtual laboratory and practical work: an extension of the technology acceptance model," Computers \& Education, vol. 135, pp. 1-14, 2019.

[57] S. T. Stola and M. F. Young, "Stories, games, and learning through play: the affordance of game narrative for education," in Serious Games for Educational Applications, R. Zheng and M. K. Gardner, Eds., IGI Global, Pennsylvania, USA, pp. 294-319, 2017.

[58] H. Y. Sung, G. J. Hwang, and C. J. Lin, "Experiencing the analects of confucius: an experiential game-based learning approach to promoting students' motivation and conception of learning," Computers \& Education, vol. 110, pp. 143-153, 2017.

[59] L. Hudders, V. Cauberghe, and K. Panic, "How advertising literacy training affect children's responses to television commercials versus advergames," International Journal of Advertising, vol. 35, pp. 909-931, 2016.

[60] X. S. Zhai, F. Asmi, R. T. Zhou et al., "Investigating the mediation and moderation effect of students' addiction to virtual reality games: a perspective of structural equation modeling," Discrete Dynamics in Nature and Society, vol. 2020, Article ID 5714546, 41 pages, 2020.

[61] W. Jin and P. Elliott, "Student attitudes: gaming at the college level," in Proceedings of the Northeast Asia International Symposium on Lingustics, Literature and Teaching, 2018 NALLTS, J. A. Haskell and H. Bo, Eds., pp. 565-569, ENRP Educational Technology Co Ltd; New Vision Press, Hulunbuir University, Foreign Language Teaching Research Association Inner Mongolia University, Hulunbuir, China, 2018.

[62] C. C. Chang, C. A. Warden, and G. Y. Lin, "Effects of digital game-based learning on achievement, flow and overall cognitive load," Australasian Journal of Educational Technology, vol. 34, no. 4, pp. 155-167, 2018.

[63] J. C. Yang and B. Quadir, "Effects of prior knowledge on learning performance and anxiety in an English learning online role-playing game," Educational Technology \& Society, vol. 21, no. 3, pp. 174-185, 2018.
[64] Q. F. Yang, S. C. Chang, G. J. Hwang, and D. Zou, "Balancing cognitive complexity and gaming level: effects of a cognitive complexity-based competition game on EFL students' English vocabulary learning performance, anxiety and behaviors," Computers \& Education, vol. 148, Article ID 103808, 2020.

[65] R. Zheng and M. K. Gardner, Serious Games for Educational Applications, IGI Global, Pennsylvania, USA, 2017.

[66] K. Hava, T. Guyer, and H. Cakir, "Gifted students' learning experiences in systematic game development process in afterschool activities," ETR\&D-Educational Technology Research and Development, Advance Online Publication, vol. 68, no. 3, pp. 1439-1459, 2020.

[67] I. Didenko, "Game-based learning in English for specific purposes classroom," in Proceedings of the 12th International Conference on Open Education as a Way to a Knowledge Society (DisCo), Microsoft, Prague, Czech Republic, pp. 273278, 2017.

[68] J. Cha, S. Y. Kan, N. H. A. Wahab, A. N. Aziz, and P. W. Chia, "TI incorporation of Brainteaser game in basic organic chemistry course to enhance students' attitude and academic achievement," Journal of the Korean Chemical Society-Daehan Hwahak Hoe Jee, vol. 61, no. 4, pp. 218-222, 2017. 